\title{
A Living Nation or a Mythological Image? About the Chudes in Norwegian Folklore
}

\begin{abstract}
The objective of this article is to consider legends or oral narratives in Norway which deal with the Chudes. Who were the Chudes - an important nation acting in a particular historical context or a mythological image? In order to answer this question it is necessary to examine different references to the Chudes preserved in Norwegian legends and historical sources. Here I consider the following tasks: 1) to clarify the meaning of the word 'Chude' in Norwegian culture; 2) to analyze legends about the Chudes in order to pick out the main plot-constructing elements.

Legends are narratives which claim to be true and are usually connected to well-known places and people. Migrating legends are narratives which have been narrated in many places and for a long period of time. This also concerns legends narrating about the Chudes. This article discusses the effect on the percentage of truth in the narratives.

For fifteen years I have taken the lead in doing research work at UiT (The Arctic University of Norway), the Institute of Teacher Education and Pedagogy, where my students and I collected several hundred legends, mainly from Northern Norway. The reason why pedagogy students were involved in this work is that legends can be applied as a method of knowledge development. It will be helpful when the students become trained teachers and face their own pupils at primary and lower secondary schools. Interest in legends can strengthen skills and content awareness, being at the same time a gateway to establishing knowledge structures.
\end{abstract}

\section{Keywords:}

Chude, legend, historical sources, Norway, intangible cultural heritage

1 UiT The Arctic University of Norway, Kingdom of Norway. E-MAIL: roald.larsen@uit.no 


\section{INTRODUCTION}

Migrating legends are legends which have been narrated in many places, and since legends on a general basis claim to be true, in this article I consider the effects on the percentage of truth in the narratives.

In Norway there are some oral narratives dealing with the Chudes, and the article will give an answer to who they were - a real nation acting in a particular historical context or a mythological image, or maybe both? In order to answer this question, it is necessary to examine different references to the Chudes preserved in Norwegian legends and historical sources. ${ }^{2}$

\section{METHOD AND ANALYSIS}

Who were the Chudes? Here I consider the following research goals: 1) to clarify the meaning of the word 'Chude' in Norwegian culture; 2) to analyze legends about the Chudes in order to pick out the main plot-constructing elements. For this purpose I will first review the meaning of this word in Norwegian cultural tradition, but primarily, after giving different presentations, I will look into this kind of migrating legends and discuss the criterion of truth in the narratives.

Among researchers, especially folk life researchers, the following scholars have studied the semantics and the usage of this name in Norway: Lars Ivar Hansen (2001), Svale Solheim (1973), Finn Strømsted (1970), and others.

I use synchronic and diachronic method for material analysis, where material comprises a period of more than fifty years. An extensive recording of Sami legends from Norway was made by Just Knut Qvigstad at the end of the 19th and beginning of the $20^{\text {th }}$ century (Qvigstad, 1997).

\section{INTANGIBLE CULTURAL HERITAGE}

An oral narrative genre such as legends is an example of intangible cultural expressions. Intangible cultural heritage is a concept connected to active protection of intangible culture. This topic was seriously set on the political agenda by UNESCO convention on October 17, 2003. Since 2008, UNESCO has registered

This article is based on some outlines and findings presented in the book Tracing the Chudes edited by Natalia Drannikova and Roald Larsen (Arctic Publisher, 2007) dealing with the Chudes in the Barents region. 
intangible cultural heritage in the list of Masterpieces of the oral and intangible cultural heritage. The Norwegian UNESCO Committee gives the following, but not complete, definition of the concept of intangible cultural heritage: "Language, performing arts, social customs, traditional handicraft skills connected to nature are examples of intangible cultural heritage". ${ }^{3}$ Due to its peculiarity, intangible culture seems invisible in relationship to tangible cultural heritage, but it was made a sphere of special focus by UNESCO. In the global perspective, intangible cultural heritage is not only given attention to, but there are also quite many concerns relating to all oral cultural traditions and cultural knowledge which disappear every day from the repertoire of human heritage. The convention laid a foundation for a more goal-oriented and systematic effort in order to document, preserve and promote intangible cultural expressions such as oral story-telling genre [including legends - R.L.]. ${ }^{4}$

\section{WORK WITH NARRATIVES AND SOURCE USAGE}

In Norway, Chude legends are frequently a part of a living legend tradition, i.e., new legends of this type are continually produced. Therefore one will find here both newly written legends and legends which were recorded more than 100 years ago. Some stories will presumably be identified by the reader, while others will remain unknown. The purpose of my collecting work has been to hold the collected stories as close to the existing oral tradition as possible. This implies that all the different contributions appear with their own voices and modes of expression. Since I am a Nordic philologist, I wanted to present as much as it is possible a form of integrated stories, where both the contents and the nuances of language of the oral tradition are protected. Opposite to some folklorists whose intentions were often to present the written expression emphasizing the interview situation relatively close to what the informant expressed in relation to leading questions in the oral context, in my research it was attached little significance to this purpose when it comes to Norwegian legends which I collected. In the process of work with Norwegian stories an interview with an informant was almost regarded as the first step in the process of drafting an adequate text. Due to this, many texts are complicated in their form and contents; in explanations in the footnotes attached

\footnotetext{
3 https://unesco.no/kultur/immateriellkulturarv/ [access date: 17.10.2003].

4 http://unesco.no/wp-content/uploads/2012/12/UNESCOs-konvensjon-av-2003-om-vernav-den-immaterielle-kulturarven.pdf [Recommendation from the Norwegian Ministry of Foreign Affairs of June 2, 2006. Approved by the Cabinet on the same day].
} 
to a particular text I mention the chief motif in a particular story. The majority of the collected legends appear through interviews which afterwards were given a written form. Later the contributions were more or less edited. Some texts were extensively rewritten, and only the "central theme" is left. The reader will meet different expressions of different story-tellers, which creates variation and flexibility in, e.g., legend material about the Chudes. The existing written language norm was not followed servilely, but orthographic solutions with usage of allowed parallel forms were used.

An attempt was made to document the source of the legend to the possible extent. The informants are referred to in the footnotes. However, some informants wanted to remain anonymous. There were also situations where it was not possible to recall the source of the legend.

\section{MIGRATING LEGENDS VERSUS FILMS}

The Legend about Kvenflåget below is published in the book Tracing the Chudes, and is slightly edited in this context (Drannikova \& Larsen, 2007, pp. 139-140):

Once upon a time in the mid-1600s, there were some Kvens from Sweden who tried to plunder villages along Salten fjord. At that time there was great famine in this area, and they were wandering in order to plunder food and valuables from the estates along the coast. For this purpose they crossed the border reaching the place named Skjønståldalen. The valley had got this name because it was located near a beautiful river. In Solvikmarka they came across a Sami whose name was Pål. He had settled down here as a small farmer under control of one of the estates at Leifseth. The Kvens made Pål be their guide, but the Sami man understood what was their purpose and made up a plan on how he would rescue large farmers from the robbers. He told the Kvens about a great party at Leifseth estate where the large farmer Jacob Willumsøn was going to celebrate his son's wedding. Pål agreed to show the Kvens the way over the mountain, but he thought it would be smartest to wait until the evening, as profit would be biggest when great people gathered to celebrate.

It happened in winter, and when it started to get dark they hit the road skiing over the mountain. Gradually it became so dark that the Sami man had to light the torch in order to show the way. From the top, the mountain plunged down to the fjord, and when they approached the edge, one could hear breaking waves below. "It's just the bride and the bridegroom singing and shouting”, said Pål. Then he asked the Kvens to follow him and the torch and ran off the mountain. Close by the edge there was a big stone and Pål dashed to the side behind the stones and threw the torch off the cliff. It is said that the last Kven was stuck hanging on the birch at the top of the steep slope. He understood what had happened and was so angry that he threatened to kill Pål if he caught him. But then the Sami man pulled out his knife 
and cut down the birch so that also the last of the robbers fell into the abyss. And then Pål ran directly to the large farm Leifseth, opened the door of the feast hall and shot an arrow over the head of the bride and the bridegroom before telling what had happened. At first nobody believed him, and he was taken for being drunk. Pål agreed to be under arrest on the farm until next day when he took with himself some people who could see with their own eyes all the robbers lying badly injured down the steep slope. And then he was generously rewarded.

After this incident the steep slope got the name Kvenflåget.

The Legend about Kvenflåget is a migrating legend and describes how the Sami man Pål lures the Kven robbers down the cliff. Migrating legends are legends which have been narrated in many places and for a long period of time. Legends are narratives which claim to be true and are usually connected to well-known places and people. It concerns also migrating legends. But although the legends claim to be true, it does not necessarily mean that the person narrating it believes in it. Migrating legends have been narrated first and foremost because they are good stories. Legends are not primary sources to folk beliefs.

On October 24, 2007, the newspaper "Nordland" in Bodø5 referred to Kvenflåget located between Fauske and Saltdalen, the southern part of Northern Norway which, according to the newspaper, could have been the backcloth for the 1987 Sami film The Guide ${ }^{6}$ which script was based on some legends about the Chudes. In the newspaper it is referred to the same dramatics taking place in the film in the $12^{\text {th }}$ century in Eastern Finnmark which could have happened in the $17^{\text {th }}$ century in Kvenflåget. It can be said, one cannot deny, that actually a similar incident could have happened near Kvenflåget - many hundred years after the legend had been written in Eastern Finnmark. History indicates that such conflict could have happened in Eastern Finnmark, in border areas between Finland and Russia (as it appears in the film). One can imagine the following scenario: let us assume that in any case there have been great action here and many people, who have experienced it, have narrated further this story, and this legend has afterwards lived its own life and wandered over a large territory. There was great contact between people in Northern Norway at that time. Dried fish export from Lofoten started to the fullest in the $12^{\text {th }}$ century. The largest boat-builders were the Sami - they were fishing in Lofoten as boat sellers or fishermen. Here people from the whole Northern Norway met each

\footnotetext{
"Nordland Newspaper" is the second largest newspaper in Northern Norway when it comes to circulation.

$6 \quad$ The Guide is a 1987 Norwegian film directed by Nils Gaup. It was nominated for an Oscar and was the first feature film in the Sami language which has ever been produced. The script is based on migrating legends from the $12^{\text {th }}$ and $13^{\text {th }}$ centuries and deals with a young Sami guide who overpowers a murderous tribe called the Chudes from the East, leading them down the cliff.
} 
other, and stories were perhaps narrated, and legends could thus wander over the whole province. Some fishermen, who were from places near Kvenflåget, could have heard this legend from Eastern Finnmark and adapted it to local conditions. It is not surprising that a well-known cliff needed its story, its legend. What would be more natural than telling a dramatic story about a dramatic cliff?

The Guide film revives an old legend about robbers who bothered the Sami. In the film these robbers are called the Chudes. Legends about the Chudes have been published in Norway by, e.g., Just Knut Qvigstad (1997), Olav Bø et al. (1981), Torbjørn Storjord and Lars Stærk (1991). At the end of the 19th and the beginning of the $20^{\text {th }}$ century, J.K. Qvigstad collected, as it was mentioned, a large number of Sami fairy-tales and legends. His collections contain 21 legends about the Chudes who come into collision with the Norwegian Sami and the Russian Sami who lived on the Kola Peninsula. L. Stærk has printed 4 legends about the Chudes. There still exists a living legend tradition about the Chudes in Northern Norway. Since 1998 I have collected large amounts of legends in this part of the country, of which about 50 deal with the Chudes.

\section{HISTORICAL SOURCES ABOUT THE CHUDES}

Based on historical sources, Lars Ivar Hansen writes that events connected to the Chudes originate from medieval circumpolar Scandinavia (Hansen, 2001, p. 28). Olav Bø claims that such legends appeared probably in the northern border regions of Norway (Bø et al., 1981, p. 297), which is a border between present-day Russia and Finland, but also in the border area of Sweden it is certified by Lulesami legends, which were recorded (Storjord, 1991, p. 16).

Sami narrations about the Chudes go probably deep into memories about pirate raids against these people. Already at the end of life and times of Ottar, who was an Old Norwegian leader, it is narrated about Finnish-speaking Kvens who undertook pirate raids in Northern Norway. The Kvens were a separate nationality (Gallén \& Lind, 1991) who could have been in conflict with the Norwegians. The parts often attacked each other. They plundered and devastated each other's territories. From the end of the $12^{\text {th }}$ century, old-Norwegian sources describe Kvenland as a territory situated on the border between Finland and Karelia (Hansen, 2001, p. 19). From the $18^{\text {th }}$ century, the word 'Kven' has got a new meaning - a Finn who has immigrated to Northern Norway.

At the beginning, the Norwegian government considered Sami settlement area (Sameland or Finnmark) as the king's territory and verified in the course 
of time its right to lay a tax on the Sami (Hansen, 2001, p. 18). Several centuries before this territory had been a place of conflicts and mutual pirate raids (Hansen, 2001, pp. 25-26). At the beginning of the $13^{\text {th }}$ century, the Karelians, who are related to the Kvens, became representatives of the Novgorod republic. At the end of the $15^{\text {th }}$ century, they acted on behalf of Moscow. The Karelians considered coast territories in Troms and Finnmark as an area which was useful to have at their disposal, and they could advance hard forward. There were registered 11 Karelian raids on these coast territories of Northern Norway in the period from 1250 to 1444 (Hansen, 2001, p. 18).

\section{MANY PROOFS}

Innumerable stories about the Karelian Chudes or the Russian Chudes who attacked local population in Finnmark and Troms (today the northernmost county in Norway) reflect historical events (Dahl, 2004, p. 373). One should take into consideration a chance to call neighboring nations in Scandinavia who collected money, the Chudes. Torbjørn Storjord published legends about the Chudes where the informants were the Lulesami from Nordland at the Swedish border. The Chude image shown in the legends cannot refer to the Karelians or other Finno-Ugric peoples (Storjord, 1991, p. 61), and it is most probable that this name was used here in reference to the Swedes. The name "Chude" was adapted to local contacts with other ethnic groups in different Sami regions (Hansen, 2001, pp. 27, 28-30): the Sami could call the Norwegians and Swedes the Chudes if they attacked them.

The guide theme exists also in Danish folklore. Here the Swedes appear as enemies. The guide leads the Swedes to thin ice when they try to cross Danish bays and straits. The content of the legend belongs to border-war period between Denmark-Norway and Sweden in the $17^{\text {th }}$ century.

\section{COULD HAVE HAPPENED}

Since the $17^{\text {th }}$ century there has existed predanie in Russian folklore about Ivan Susanin who had been taken prisoner by Polish forces and who had led Polish soldiers to a place where they were attacked from behind. During World War II, this theme appeared both in the Soviet Union and in Norway (Bø et al., p. 297). The legend about a guide is still a part of the living legend tradition in Northern Norway (Larsen \& Larsen, 2002, p. 127). 
One cannot deny that in fact a similar incident could have happened near Kvenflåget many hundred years after the legend had been recorded in Eastern Finnmark. However, it is interesting that the core and the structure of the story have strong similar features with corresponding legends further north.

The fact that there is often lack of historical sources as documentation of the percentage of truth in this kind of legends does not mean that we can deny it has happened. Legends have common people winning as the main character, and they used an oral medium. Here there are no victorious leaders gloating over a battle which was won, who could present the written form of the story.

\section{THE ETHNICON CHUDE}

The ethnicon Chude has a long history in culture connected to northern territories. Etymologically the word 'Chude' or 'cud' can be a derivative of the proto-Slavic form *tjudjo, meaning a stranger, which can be borrowed from a Gothic or a Germanic word meaning 'nation' (Myrvoll, 1999). ${ }^{7}$ Despite the fact that "nation" could have been the original meaning of the word, in the course of time it got new additional connotations which came into being as a result of contacts between the Slavonic and the Finno-Ugric peoples.

\section{THE IMAGE OF THE CHUDES IN NORWEGIAN STORY-TELLING TRADITIONS}

The image of the Chudes is preserved in Norwegian story-telling traditions. Within oral stories in Norway we find the description of the Chudes in legends. The word 'legend' originates from the verb to say and means what is being said (Solberg, 1999). Legends are short one-episode stories which are preserved in folk memory and connected to particular persons and places (Bø, 1977). When a legend can be attached to something that really happened, the truth criterion follows it. The first collectors of legends in the $19^{\text {th }}$ century considered them as historical sources (Hauan \& Skjelbred, 1995). Demands which one makes today towards historical sources reject legends as unreliable sources. Alver (1962) considers the legend as a source to people's views and attitudes, as a symbolic, meaningful story. Some legends are highly widespread and called wander legends, while others are connected to a definite area and considered local legends, place legends.

Cf. the meaning of this word in Old Norse: "nation”. 


\section{THE INFORMANTS' VIEWS ON THE CHUDE PEOPLE}

Which ethnic group do the Chudes belong to according to today's North-Norwegian informants? In my first published legend book (2002) there are legends which state that this invader-nation came from the East (Larsen \& Larsen, 2002, pp. 30, 31, 53-57). In the first two legends the raiders were called the Russians, and in the third legend - the Karelian raider groups, but also the Chudes and the Russians, on the assumption that "those who came, were so numerous". In the fourth legend, the Chudes are raider groups from Russia and Finland. In the legend by J.K. Qvigstad the names 'Russian Chudes' and 'Karelian Chudes' are used mixed up with each other. a compound word 'Russian Chudes' is used many times, but there is also mentioned the name 'Karelian Chudes' in the collection (Qvigstad, 1997, pp. 242-267: nos. 96, 97, 100, 107, 111, 114). This allows us to come to a conclusion that the name 'Chude' lets us use a wider interpretation - it was used as a description of different ethnic groups who came to Northern Norway from the East. Finn Strømsted also agrees on that and claims that the word 'Chude' means probably raider groups from the East who have different ethnic background (Strømsted, 1970, p. 9).

\section{TRACES OF THE CHUDES IN PLACE NAMES}

The name 'Chude' and its functioning in the Sami and Norwegian language can be analyzed based on the example of place names. The place name Russehølet means a place where the river zigzags and where the Karelian Chudes were deceived to death; Russeflåget - where the Karelians were deceived outside. These are examples from J.K. Qvigstad's collection. The place name Mannedrapet is taken from the first legend book published in 2002. It is the name of a place where the Chudes surprised the community and killed everyone. The Lulesami word Tjudihårrå [Norwegian Tsjuderøysene ('Chude heap of stones')] refers to 17 bourocks left after 17 Chudes from Kjerris in Nordland (Storjord, 1991, p. 61). The place name gave the name to the legend Tsjudihårrå which was published by Torbjørn Storjord. The given place names certify once again that the word 'Chude' includes 'strangers' who had a raider role regarding the Sami. 


\section{TIME-INDETERMINATE STORIES}

Stories about the Chudes who raid in circumpolar territories are time-indeterminate. Some informants who I talked to were unsure when the events could have taken place, but they supposed that it could have been some time in the $18^{\text {th }}$ or $19^{\text {th }}$ century. The majority of the informants used wording "in old days", "long ago", or "very long ago", like what was for example written in the legend from Northern Troms (the legend The Chudes Come to Furuflaten) (Larsen \& Larsen, 2002, pp. 57-58). In modern folklore the texts about the Chudes are reported in past tense dealing with something which happened once upon a time, but not now. But in Qvigstad's time, at the end of the $19^{\text {th }}$ and beginning of the $20^{\text {th }}$ century, they were still reported in present tense.

\section{"INTERNAL" TEXTS}

Legends about the Chudes belong to the so-called "internal" texts which raise the value of border communities in the neighbors' eyes. a legend is connected to a specific historical event and period, and can be still actual in another period and connected to other events (Solheim, 1973, p. 142). a legend can be based on real events (Strømsted, 1970, p. 9). Plots about the Chudes were widespread in many places and were recorded at various times and can be based both on real events or be mythologized.

\section{LEGEND TYPES}

Legends are not structured as fairytales and also differ from the latter in contents. Legends differ from fairytales in a way that the former narratives claim to be true. While fairy-tales are not connected to certain places and in addition happen in indeterminable time, connection to the reality of the legends is strengthened by events which, as is often stated, have happened in a given place with given people (Larsen \& Levit, 2008).

Let us take two examples which are still living in folklore (Drannikova \& Larsen, 2007, pp. 70-71, 103). The first legend, The Sami Hide Underground, narrates about the Sami who used to have turf huts in the ground where they used to escape fearing the Chudes. One Chude who was wandering alone, accidentally heard a conversation from the ground and understood that people must have hidden 
themselves there. This Chude was lame and had a cane, and he stuck the cane into the ground. The Chude ran away in order to warn the other robbers. a Sami who saw that, took the cane and stuck it down on the place far away. When the Chudes found the place where the cane was now standing, they searched for people but did not find anyone. The robbers became so angry at the Chude who had told them about the people that they beat him to death as they thought he had lied to them.

Another legend, The Russians and Thunder, narrates about the Russian Chudes who were wandering once upon a time. When a thunderstorm began and when they heard its sound they said to God: "You are the Lord in the sky and we - on earth". But thunder rumbled, the earth cracked under the feet of the Russian Chudes and they sank down. So they saw who the lord was also on the earth.

As mentioned earlier, among Norwegian Chude legends there are some texts with a theme where the Chudes, directed by a signpost, fell down a steep. There are different variants of this legend, but I will focus on the most widespread. Armed strangers penetrate into a living territory of another nation. They hope to attack the village unexpectedly for the victims and therefore they need a signpost. They go to the mountains and meet a man, often a Sami, who they make show them a shortcut over the mountains. The Sami man goes ahead and holds a torch in his hands. He asks the enemies to follow the torch light and leads them, who are skiing or using a sleigh, to the steep. Then he throws the torch forward over the steep, but rolls to the side and rescues his life grasping a tree or a stone. The Chudes fall down the steep, hurt themselves badly and die.

Typologically there are stereotypes in Norwegian legends which have been formed as composition-narration stereotypes. In Norwegian folklore the themes are often about a Sami guide who leads the Chudes to the steep, to the river, to white water (waterfall) (Qvigstad, no. 98), to fast water or thin ice (Itkonen, 1931). In one case, a Sami guide leads the Russians to an island where there are a lot of cloudberries. He leaves them there and finally they die of hunger (Qvigstad, no. 108).

In some legends, a guide (often a woman-guide) decoys the enemies into a fast-moving river or a waterfall (Qvigstad, nr. 98) where they die. As I have already mentioned, the historical sources certify that narrations about the Chudes are undoubtedly based on historical events. From early Middle age, Northern Norway was a "no man's land” between Russia, Finland, and Norway. Legends about a guide and the Chudes are connected only to specific territories. a narration with the same theme was recorded by the Lulesami close to the Swedish border. An example is the legend about Kvenflåget which still exists in Saltdal in Nordland (Larsen \& Larsen, 2002, p. 135). There it is told about a Sami guide who led the Kvens to the steep. 


\section{HOW DID LOCAL PEOPLE PERCEIVE THE CHUDES IN DIFFERENT HISTORICAL PERIODS?}

How did local people in Norway view the Chudes in different historical periods? Legends from Northern Norway which were recorded during the whole $20^{\text {th }}$ century convey that "they spread evil", as it is, e.g., said about the Chudes in one of the most notable legends, The Last Great Battle with the Raiders (Stærk, 1994, pp. 21, 29).

The informants who gave me the material about the Chudes evaluated them rather unambiguously. All of them call the Chudes the invaders. Words with negative connotations - raider groups, raiders, etc. - convey precisely the attitude to the Chudes. The examples are taken from the legends The Murder of a Man and The Russians Who Were Reflected in Fish Grease, which were published in the first legend book in 2002 (Larsen \& Larsen, 2002, pp. 30, 53).

\section{ACTING STEREOTYPES}

In the legends the Chudes are given acting stereotypes which are typical for representatives of "the world of strangers". Stupidity of the Chudes is exaggerated; their acting and appearance are abnormal. They are dressed in black clothes and speak a kind of an artificial language (Stærk, 1994, pp. 21, 29). The Chudes are deceived, so that at the end of the stories they fall down the steep, lose clothes or freeze to death. Some raiders remain on the desert islands and die of hunger. The storms destroy their boats, and they drown, and sometimes the Chudes kill each other. Physical strength of the Chudes is hyperbolized. Struggling against them, a Sami has to seek help with Sami shamans, medicine men. Qvigstad published a legend about the Russian Chudes who were defeated by magic (no. 100). In the legend, the Chudes seek help with a spirit. In order to win over the Sami they got Stállu who fought against the Sami (Qvigstad, no. 112). Murder weapon of the Sami, which was used against Stálluen, was an iron object (in the legend - a sheath knife).

\section{FEATURES OF HAGIOGRAPHICAL STORIES AND FAIRY-TALES}

Some legends have features of hagiographical stories. Olav Bø has published a legend, Russevåg (Bø et al., 1981, pp. 164-165), where the God destroys the sight of the raider horde. In the legend The Russian and Thunder (which I referred to earlier), where the Chudes start to mock the God, the Lord tears the earth with 
lightning, and the Chudes sink down into a split. In the legend Single Combat at Sabbenjarga (Qvigstad, no. 106), the Russian Chudes pray to God and afterwards they get help from him. The theme of punishment for boasting can be found in the legend Boasting Is Punishable (Qvigstad, no. 104). Three Sami brothers kill a group of Chudes, but let one of them survive, and they ask him boastingly to come back next year with another group because then they will kill this new group. As a result, the Chudes kill all three Sami men.

\section{SUMMARY AND CONCLUSION}

Migrating legends are narratives which have been narrated in many places and for a long period of time. This concerns also legends narrating about the Chudes. In this article, it is discussed in connection to The Legend about Kvenflåget how it affects the percentage of truth in the narratives. The fact that there is often lack of historical sources as documentation of the percentage of truth in this kind of legends does not mean that we can deny it has happened. Here there are no victorious leaders who could gloat over a battle which was won, and who could present the written form of the story.

In Norwegian culture the ethnonym 'Chude' means raiders of different ethnical belonging who came from the East in order to plunder the population in Northern Norway. As research showed, this name could be particularly used in reference to the Russians, Finns, Karelians, and Kvens.

The word 'Chude' has a historical and mythological context. Legends about the Chudes have preserved "memories" about the historical past of the northern region. The themes about militant and plundering Chudes are located in Sami regions of Norway. In legends, the Sami belong to "our” world, while the Chudes are connected to ideas about the world of the "strangers". The name 'Chude' means 'a stranger', 'a raider'.

\section{References}

Alver, B. (1962). Historical Legends and Historical Truth. København: Nordisk Institut for folkedigtning.

Bø, O. (1977). Fairy-tales II: Norwegian Folk Poetry II. 3. utgåva. Oslo: The Norwegian Samlaget.

Bø, O., Grambo, R., Hodne, B., \& Hodne, Ø. (1981). Norwegian Legends. Oslo: The Norwegian Samlaget.

Dahl, B.H. (2004). Russian Occupation of Finnmark in the $15^{\text {th }}$ Century. Harstad: Håløygminne. Drannikova, N., \& Larsen, R. (Eds.) (2007). Tracing the Chudes. Tromsø: Arctic Publisher. 
Fagertun, F., Ryymin, T., \& Myhre, J.E. (Eds.) (2001). The Dangerous North: Threats and Threat Perceptions Related to Northern Norway through a Thousand Years [Report from the 25th North-Norwegian History Seminar, Tromsø, 29.09.-1.10.2000]. Institute of History, University of Tromsø.

Gallén, J., \& Lind, J. (1991). Nöteborg Peace and Eastern Border of Medieval Finland. The Second Part, the Third Part (with Maps). [The Publication Printed by the Swedish Literature Company in Finland). Helsingsfors.

Gaup, N. (dir.) (1987). The Guide [North-Sami original title: Ofelaš]. a Sami Film.

Hansen, L.I. (2001). The Border Settlement on the Northern Calotte from the Middle Ages to 1751: Peoples - Strategies - Principles. In: F. Fagertun, J.E. Myhre, \& T. Ryymin (Eds.), The Dangerous North. Threats and Threat Perceptions Related to Northern Norway through a Thousand Years. Writing Series from the Department of History (pp. 11-51). University of Tromsø, Tromsø, No.1.

Hauan, A.M., \& Skjelbred, A.H.B. (1995). Between Legends and Reality in the North Norwegian Tradition. Stabekk: Vett og Viten.

Itkonen, T.I. (1931). Koltan-ja kuolanlappalaisia satuja. Helsinki: Suomalais-ugrilainen seura.

Larsen, A.S., \& Larsen, R. (Eds.) (2002). Headless Men and Frozen to Death Hikers. Eureka Publisher.

Larsen, R., \& Levit, L. (2008). Norwegian Folklore. a Teaching Aid for Russian Speakers. Tromsø: Arctic Publisher.

Liestøl, K. (Ed.) (1977). Norwegian Folk Poetry. Legends. With a Preface and Comments by Knut Liestøl. Oslo: Det norske Samlaget.

Myrvoll, M. (1999). The Sami: One Nation in Four Countries. Sami Contents in the Curriculum: a Resource Book for Teachers at Primary and Lower Secondary School. Kautokeino: The Sami Educational Council.

Nordland Newspaper (2007). [A Local Tabloid Newspaper Published Daily in Bodø and Neighbouring Municipalities in Salten. Both Paper and Internet Version].

Solberg, O. (1999). Norwegian Folk Poetry: Literary and Historical Lines and Thematic Perspectives. Oslo: LNU, Cappelen Academic Publishing.

Solheim, S. (1973). Historical Legends - Historical Function. Norwegian Periodical for Research of Everyday Life, 16.

Stærk, L. (1994). Fairy-Tales and Legends from Sør-Varanger. Kárásjohka: Davvi Girji.

Storjord, T. (1991). Lulesami Fairy-Tales and Legends. Bodø: Bodø Pedagogical College Publication Series No. 2.

Strømsted, F. (1970). Nakkul og Lainit: Sami Fairy-Tales. Oslo: Minerva Publisher.

Qvigstad, J. (1997). Sami Narratives. Introduction, Comments and Language Adaptation by Brita Pollan. Illustrations taken from Ernst Manker: Sami Art. In a Collection of J.K. Qvigstad’s Sami [i.e., Lapp] Fairy-Tales and Legends I-IV, 1927-1929. Aschehoug Publishing.

\section{Online Sources}

https://unesco.no/kultur/immateriellkulturarv [access date: 17.10.2003].

http://unesco.no/wp-content/uploads/2012/12/UNESCOs-konvensjon-av-2003-om-vern-avden-immaterielle-kulturarven.pdf [Recommendation from the Norwegian Ministry of Foreign Affairs of June 2, 2006. Approved by the Cabinet on the Same Day]. 